\title{
DESAIN SISTEM INFORMASI DAN LAPORAN KEUANGAN PADA ORGANISASI NIRLABA
}

\author{
Mardiana Andarwati \\ Fakultas Teknologi Informasi, Universitas Merdeka Malang \\ mardiana.andarwati@unmer.ac.id
}

\begin{abstract}
A nonprofit information system for recording transactions of non-profit organizations cash receipts, cash disbursements, buying, selling of products/ services, depreciation does not exist the difference with the business organizations. But what makes the difference is the party be the owner, until no transactions related to sales a change of ownership or allocation of funds/resources from liquidation. If The non-profit organizations to generate profits, no transaction is used for distribution of profits to the founder or owner. Given the non-profit organizations need financial statements to provide relevant information and to meet the interests of the donors, the organization's members, creditors, and other parties provide resources for nonprofit organizations.
\end{abstract}

\section{Keywords : system information, financial report, nonprofit organization}

\section{PENDAHULUAN}

Masing-masing organisasi pasti mempunyai sistem informasi, hal ini berlaku baik bagi organisasi publik yang besar atau pada suatu organisasi yang hanya terdiri dari beberapa orang yang berkumpul bersama untuk mencapai tujuan bersama.

Bagi suatu perusahaan di sektor publik (organisasi non komersial) sistem informasi yang dimiliki oleh suatu organisasi banyak berkaitan dengan masa lalu, dalam arti kata penanganan catatan-catatan tentang apa yang telah berlaku dalam organisasi. Tetapi juga berkaitan dengan saat ini saat itu juga berkaitan dengan masa yang akan dating.

Organisasi di sector publik adalah organisasi yang tidak bertujuan mendapatkan laba, biasanya kegiatannya lebih banyak berhubungan dengan aktivitas sosial dan pelayanan masyarakat.

Organisasi ini dimiliki secara kolektif oleh masyarakat/publik. Kategori organisasi jenis ini sebenarnya masih bisa diklasifikasikan lagi menjadi dua yaitu lembaga pemerintahan dan lembaga non pemerintahan (organisasi nirlaba)

Organisasi nirlaba berbeda dengan organisasi bisnis, perbedaan yang paling signifikan adalah pada cara organisasi tersebut memperoleh sumber daya. Organisasi bisnis memperoleh sumber daya dari modal pemilik sedangkan organisasi nirlaba memperoleh sumber daya dari sumbangan anggota atau masyarakat baik yang mengikat maupun tidak mengikat.
Desain sistem dan prosedur pengelolaan informasi nirlaba adalah pencataan transaksi organisasi nirlaba dari penerimaan kas, pengeluaran kas, pembelian, penjualan produk/jasa, penyusutan tidak ada perbedaannya dengan organisasi bisnis. Namun yang membuat berbeda adalah pihak yang menjadi pemilik, hingga tidak ada transaksi yang berhubungan dengan penjualan perubahan kepemilikan atau tidak adanya alokasi dana/sumber daya hasil likuidasi. Seandainya organisasi nirlaba tersebut menghasilkan laba, tidak ada transaksi yang digunakan untuk pembagian laba kepada pendiri atau pemilik. Mengingat organisasi nirlaba memerlukan laporan keuangan untuk menyediakan informasi yang relevan dan untuk memenuhi kepentingan para penyumbang, anggota organisasi, kreditur, dan pihak lain yang menyediakan sumber daya bagi organisasi nirlaba.

Sesuai dengan latar belakang yang telah disampaikan di atas maka perumusan masalah yang dibahas secara umum adalah bagaimanakah desain sistem dan prosedur pengelolaan informasi akuntansi pada organisasi nirlaba?

Permasalahan khusus adalah (a) bagaimanakah karakteristik sistem informasi akuntansi pada organisasi nirlaba, (b) bagaimanakah desain sistem pengelolaan informasi akuntansi yaitu sistem yang terkait pada organisasi nirlaba?

Tujuan dari penelitian adalah

(a) Dapat menjelaskan karakteristik sistem informasi akuntansi pada organisasi nirlaba 
(b) Dapat mendesain sistem informasi akuntasi yang terkait dengan organisasi nirlaba.

Manfaat penelitian adalah

(a) Sebelum melakukan desain sistem informasi akuntansi yang terkait dengan organisasi nirlaba maka harus memahami karakteristik organisasi nirlaba yang terkait dengan sistem informasi akuntansi

(b) Dengan memahami dan dapat mendesain sistem informasi akuntansi nirlaba maka akan dapat lebih mempercepat dan mempermudah proses transaksi pada organisasi nirlaba.

(c) Untuk lebih memudahkan pengelolaan informasi akuntansi yaitu sistem yang terkait pada organisasi nirlaba.

\section{Desain Sistem dan Prosedur Informasi Akuntansi \\ Pengertian Sistem}

James A. Hall, 2004, a system is a group of two or more interrelated components or subsystems that serve a common purpose, kemudian menurut Romney \& Steibert , 2006 hal 4, a system is a set of two or more interrelated components that interact to achieve a goal.

Menurut James A. Hall, 2004, information is often defined simply as processed data. Information is determined by the effect it has on the user, not by the physical form. Karakteristik dari informasi (Menurut James A. Hall, 2004)

1. Relevance : Isi dari laporan atau dokumen harus sesuai dengan tujuan.

2. Timeliness : Umur dari informasi adalah faktor penting untuk memastikan kegunaannya.

3. Accuracy : Informasi harus bebas dari kesalahan material.

4. Completeness : Segala bentuk dari informasi yang penting untuk mengambil keputusan atau tugas tidak boleh hilang.

5. Summarization : Informasi sebaiknya diringkas sesuai dengan kebutuhan pemakai.

Menurut Roomney \& Steinbart, 2006 hal 56, information is data that have been organized and processed to provide meaning to a user.

Karakterisrik dari informasi (menurut Romney \& Steinbart, 2006)

1. Relevant : Informasi mengurangi ketidakpastian, meningkatkan kemampuan pengambil keputusan untuk membuat prediksi, atau memastikan atau mengoreksi harapan sebelumnya.

2. Reliable : Informasi bebas dari kesalahan atau bias dan dengan akurat mewakili aktivitas dari organisasi.

3. Complete : Informasi tidak melewatkan aspek penting dari aktivitas dasar organisasi

4. Timely : Informasi disediakan tepat waktu untuk pengambil keputusan untuk membuat keputusan

5. Understanable : Informasi disajikan pada format yang berguna dan dapat dimengerti

6. Verifable : Dua orang berpengetahuan melakukan tindakan sendiri dan dapat menghasilkan dengan informasi yang sama

7. Accessible : Informasi tersedia untuk pemakai pada saat dibutuhkan dan didalam bentuk yang dapat digunakan

\section{Pengertian Desain Sistem}

Mendesain sistem adalah sebuah proses menerjemahkan kebutuhan pemakai informasi ke dalam alternative rancangan sistem informasi. Desain sistem dilakukan berdasarkan informasi yang didapatkan oleh analis sistem (Mulyadi, 2001:51).

Jogiyanto (2001:196) mendefinisikan desain sistem sebagai penggambaran, perencanaan, dan pembuatan sketsa atau pengaturan beberapa elemen yang terpisah ke dalam satu kesatuan yang utuh dan berfungsi.

Menurut Purnomo (2001:33) perancangan sistem merupakan sebuah proses yang terdiri atas beberapa kegiatan, yaitu sebagai berikut

1. Menentukan secara tepat danm terperinci kebutuhan dan bentuk informasi yang sebenarnya diperlukan untuk menunjang keberhasilan operasional perusahaan yang berkaitan dengan kegiatan pengolahan data yang dikehendaki oleh manajemen

2. Mengatur semua kebutuhan serta membaginya secara sistematis pada beberapa tahap dan bagian, yang nantinya aka dioperasikan secara standar untuk menghemat waktu dan biaya

3. Menentukan cara pelaksanaan tiap-tiap tugas terebut

4. Menentukan tinkat ukuiran mutu untuk menilai keberhasilan dan ketidakberhasilan dari tiap-tiap performa tugas-tugas tersebut

5. Menghilangkan sebanyak mungkin pekerjaan yang akan menghambat implementasi sistem, 
seperti terjadinya duplikasi (pengulangan yang tidak perlu) mengenai fungsi, tujuan, dan operasi

6. Data, formulir-formulir data masukan dan laporan-laporan yang sejenis. Di samping itu juga mengurangi sebanyak mungkin hal-hal yang tidak bermanfaat yang mungkin terdapat dalam sistem dan prosedur, aliran data yang tidak efisien, dan laporan-laporan yang kurang bermanfaat atau bahkan tidak berguna

\section{Pengertian Sistem Informasi}

Menurut James A. Hall (2004) information system is the set of formal procedures by which data area collected processedbinto information and distributed to users.

Definisi sistem informasi menurut Ali Masjono Mukhtar, adalah "Suatu pengorgaisasian peralatan untk mengumpulkan, menginput, memproses, menyimpan, mengatur, mengontrol, dan melaporka informasi untuk pencapaian tujuan perusahaan"

\section{Pengertian Sistem Informasi Akuntansi}

Menurut James A Hall (2004) the accounting information system comprises 3 major subsystem

1. The transaction processing system (TPS)

2. The general ledger reporting system (GL/FRS)

3. The management reporting system(MRS)

Pengertian sistem informasi akuntansi menurut Cushing (1995:17) adalah kumpulan manusia dan sumber daya modal dalam suatu organisasoi yang bertanggung jawab untuk penyediaan informasi data transaksi. Menurut Baridwan (2000:4) sistem informasi akuntansi adalah suatu komponen organisasi yang mengumpulkan, menggolongkan, menganalisis, dan mengkomunikasikan informasi keuangan yang relevanm untuk pengambilan keputusan, baik kepada pihak luar, seperti pajak, investor, dan kreditor, maupun pihak dalam perusahaan terutama manajer.

Menurut Romney dan Steinbart (2006:67) accounting informationm system is system that collects, records, stores, and processes data to produce information for decision makers. There are six components of an AIS.

1. Pengguna yang mengoperasikan sistem dan melakukan berbagai macam fungsi

2. Prosedur dan instruksi baik manual dan otomatisasi, terkait di pengumpulan, pemrosesan, dan penyimpanan data tentang aktivitas organisasi.

3. Data tentang organisasi dan proses bisnis organisasi.

4. Perangkat lunak digunakan untuk memproses data organisasi.

5. Infrastruktur dari teknologi informasi, termasuk computer alat pelengkap, dan alat jaringan komunikasi yang digunakan untuk mengumpulkan, pemrosesan, dan pengiriman data dan informasi.

6. Pengukuran control internal dan keamanan yang menjaga data di AIS.

Manfaat dan fungsi Sistem Informasi Akuntansi menurut Romney \& Steinbart, 2006

a. Meningkatkan kualitas dan mengurangi beban dari produk dan jasa

b. Meningkatkan efisiensi

c. Membagi pengetahuan

d. Meningkatkan efisiensi dan keefektifan alur penyaluran

e. Meningkatkan struktur control

\section{Organisasi Nirlaba}

Organisasi nirlaba atau organisasi non profit adalah suau organisasi yang bersasaran pokok untuk mendukung suatu isu atau perihal di dalam menarik perhatian publik untuk suatu tujuan yang tidak komersil, tanpa ada perhatian terhadap hal-hal yang bersifat mencari laba (moneter). Organisasi nirlaba meliputi gereja, sekolah negeri, derma publik, rumah sakit dan klinik publik, organisasi politis, bantuan masayarakat dalam perundang undangan, organisasi jasa sukarelawan, serikat buruh, asosiasi professional, institute riset, museum, dan beberapa para petugas pemerintah. Di Indonesia organisasi nirlaba telah berkembang cukup pesat terutama di bidang keagamaan serta advokasi. Selain itu di bidang pendidikan kini juga mulai berkembang seperti yang dilakukan oleh Interviews Indonesia, dimana mereka melakukan bimbingan bagi para jurnalis (Wikipedia Ensiklopedia Bebas).

Menurut PSAK Nomor 45 bahwa organisasi nirlaba memperoleh sumber daya dari sumbangan para anggota dan para penyumbang lain yang tidak mengharapkan imbalan apapun dari organisasi tersebut (IAI, 2004:45.1)

Lembaga atau organisasi nirlaba merupakan suatu lembaga atau kumpulan dari beberapa individu yang memiliki tujuan tertentu dan bekerja sama untuk mencapai tujuan tadi, dalam 
pelaksanaannya kegiatan yang mereka lakukan tidak berorientasi pada pumupukan laba atau kekayaan semata (Pahala Nainggolan, 2005 : Suatu organisasi pada dasarnya bisa dibedakan menjadi dua kategori (Dedhy Sulistiawan, 2007)

a. Organisasi bisnis/komersial (swasta)

Organisasi ini bertujuan mendapatkan laba sebanyak-banyaknya bagi pemilik. Semakin besar laba yang diperoleh maka bisa dikatakan organisasi tersebut semakin menarik secara finansial. Organisasi ini biasa disebut sebagai perusahaan seperti CV (persekutuan), PT (Perseroan Terbatas), perusahaan perseorangan.

b. Organisasi non komersial (sektor publik)

Organisasi ini tidak bertujuan untuk mendapatkan laba, biasanya kegiatan ini lebih banyak berhunbungan dengan aktivitas social dan pelayanan masyarakat. Misalnya rumah sakit, yayasan, sekolah, universitas, partai politik. Organisasi jenis ini diklasifikasikan menjadi dua yaitu lembaga pemerintahan dan lembaga non pemerintahan (organisasi nirlaba).

\section{Desain Sistem Pengelolaan Informasi Akuntansi pada Organisasi Nirlaba}

Desain sistem pengelolaan informasi akuntansi nirlaba adalah mendesain sistem mulai dari pencatatan transaksi organisasi nirlaba pada penerimaan kas, pengeluaran kas, pembelian, penjualan produk/jasa. Namun untuk penyusutan tidak ada perbedaannya dengan organisasi bisnis. Namun yang membuat berbeda adalah pihak yang menjadi pemilik, hingga tidak ada transaksi yang berhubungan dengan penjualan/perubahan kepemilikan, atau tidak ada alokasi dana/sumber daya hasil likuidasi.

Seandainya organisasi nirlaba tersebut menghasilkan laba, tidak aka nada transaksi yang digunakan untuk pembagian laba kepada pendiri atau pemilik. Mengingat organisasi nirlaba memerlukan laporan keuangan untuk menyediakan informasi yang relevan dan untuk memenuhi kepentingan para penyumbang, anggota organisasi, kreditur dan pihak lain yang menyediakan sumber daya bagi organisasi nirlaba.

\section{METODE PENELITIAN}

Metode yang digunakan dalam perancangan sistem kerja dan prosedur-prosedur untuk melakukan suatu kegiatan adalah memperbaiki sistem yang sudah ada dan menjadi suatu sistem yang baru sehingga perusahaan atau organisasi yang bersangkutan akan mendapatkan kemudahan dalam mengetahui informasi dengan lebih cepat dan akurat. Adapun perancangan sistem semuanya dilakukan melalui metode Data Processing (DP). Sistem pengolahan data dengan menggunmakan computer yang dinamakan Electronic Data Processing System (EDPS) mempunyai pola umum sebagai berikut

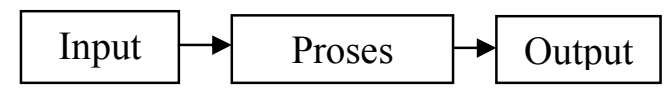

Definisi operasional yang akan diteliti yaitu meliputi konsep, variable, indikator, dan item. Konsep adalah desain sistem atau alur pengoperasian untuk organisasi nirlaba meliputi, Pembelian Tunai (purcahses), Pembelian Kredit (down payment), Pelunasan Hutang, Penjualan Tunai (sales), Penjualan Kredit, Penerimaan Piutang.

\section{HASIL DAN PEMBAHASAN} Karakteristik Sistem Informasi Akuntansi
pada Organisasi Nirlaba

Organisasi nirlaba termasuk lembaga non pemerintahan yang merupakan oganisasi yang didirikan oleh masyarakat, baik dalam bentuk yayasan, organisasi profesi, partai politik, maupun organisasi keagamaan. Secara operasional organisasi ini tidak mencari laba dan juga tidak diselenggarakan oleh pemerintah. Pengelolanya adalah orang-orang yang dipercaya oleh masyarakat dan pemiliknya adalah masyarakat.

Karakteristik organisasi nirlaba berbeda dengan organisasi bisnis. Perbedaan utamanya adalah pada cara organisasi tersebut memperoleh sumber daya. Organisasi bisnis memperoleh sumber daya dari modal pemilik atau setoran pemilik, sedangkan organisasi nirlaba memperoleh sumber daya dari sumbangan anggota atau masyarakat baik yang mengikat maupun tidak mengikat.

Organisasi nirlaba juga bisa menawarkan produk atau jasa yang tidak berbeda dengan organisasi bisnis, namun organisasi nirlaba tidak untuk bertujuan mencari laba dan seandainya entitas tersebut menghasilkan laba tidak akan pernah ada transaksi yang berhubungan dengan 
pembagian laba kepada pendiri atau pihak-pihak yang mengkalim sebagai pemilik.

Tujuan utama laporan keuangan adalah menyediakan informasi yang relevan untuk memenuhi kepentingan para penyumbang, anggota organisasi, kreditur, dan pihak lain yang menyediakan sumber daya bagi organisasi nirlaba.

Laporan posisi keuangan yaitu neraca (balance shet) untuk organisasi nirlaba formatnya sama dengan laporan keuangan bisnis. Namun ada perbedaan yang signifikan yaitu terdapat akun aktiva terikat pada bagian aktiva/asset. Akun tersebut adalah akun untuk menunjukkan bahwa aktiva tersebut dibatasi penggunaannya . Aktiva yang dibatasi penggunaannya oleh penyumbang harus disajikan terpisah dari kas atau aktiva lain yang tidak tidak terkait penggunaannya. Tidak ada bagian ekuitas karena bagian tersebut diganti menjadi bagian aktiva bersih. Alasan utamanya adalah karena organisasi ini tidak memiliki pemilik. Akun yang bisa muncul pada bagian tersebut adalah aktiva bersih tidak terikat, terikat temporer.

\section{AKTIVA}

Kas/bank

Rp.xxxx

Piutang

Perlengkapan

Biaya dibayar dimuka

Aktiva terikat *)

Tanah

Bangunan

Peralatan

Jumlah Aktiva

KEWAJIBAN

Utang dagang

Utang jangka panjang

\pm Jumlah Kewajiban

AKTIVA BERSIH

Tidak terikat *)

Terikat temporer $*$ )

Jumlah Aktiva Bersih

Jumlah Kewajiban dan Aktiva Bersih Rp.xxxx

Rp.xxxx

Rp.xxxx

Rp.xxxx

Rp.xxxx

Rp. $x x x x$

$\underline{\text { Rp. } x x x x+}$

Rp.xxxx

Rp.xxxx

$\underline{\text { Rp.xxxx }}$

Rp.xxxx

Rp.xxxx

$\underline{\text { Rp.xxxx }}+$

Rp.xxxx
Tabel 1. Format Laporan Keuangan Neraca (balance sheet) Organisasi Nirlaba

Keterangan :

Aktiva terikat adalah aktiva yang dimiliki oleh perusahaan namun penggunaannya dibatasi oleh pihak ketiga/penyumbang.

Aktiva bersih tidak terikat adalah aktiva bersih yang berasal dari kegiatan yang penggunaan dananya tidak dibatasi oleh penyumbang

Aktiva bersih terikat temporer /permanen adalah aktiva bersih yang berasal dari kegiatan yang penggunaan dananya dibatasi oleh penyumbang sampai batas waktu tertentu/permanen.

Prinsip dasar laporan Aktivitas (Laporan Perubahan Aktiva Bersih) ini adalah usaha untuk mengklasifikasikan penghasilan, sumbangan, beban, dan kerugian berdasarkan jenis ikatan kontraknya.

\section{PERUBAHAN AKTIVA BERSIH TIDAK TERIKAT}

Pendapatan dan Penghasilan

\begin{tabular}{ll} 
Sumbangan & Rp.xxxx \\
Penghasilan investasi & Rp.xxxx \\
Jasa layanan & $\underline{\mathrm{R}, x x x x}$ \\
\hline
\end{tabular}

Jumlah pendapatan dan penghasilan tidak terikatRp.xxxx

Aktiva bersih yang berakhir pembatasannya

Berakhimya pembatasan waktu

Jumlah aktiva yang telah berakhir

Pembatasannya

$\underline{\mathrm{Rp}, x x x x^{+}}$

Beban dan kerugian

Rp.xxxx

Tabel 2. Format Laporan Aktivitas Organisasi Nirlaba
Pencarian dane

Kerugian akibat kebakaran

Jumlah beban dan kerugian

\section{KENAIKAN IUMLAH AKTIVA BERSIH TIDAK TERIKAT}

Perubahan Aktiva Bersih Terikat Temporer

Sumbangan

Penghasilan investasi jangka panjang

Aktiva bersih terbebaskan dari pembatasan

Penurunan aktiva bersih terikat tempore

Rp.xxxx Rp.xxxx

$\underline{(\mathrm{Rp}, x x x x)+}$

Penurunan Aktiva Bersih Terikat Permanen

Sumbangan

Penghasilan investasi jangka panjang

Kenaikan aktiva bersih terikat temporer

Rp.xxxx

$\underline{\mathrm{R} p, x x x x+}$

p.xxxx

KENAIKAN AKTTVA BERSIH

Rp.xxxx

$\underline{\mathrm{Rp}, x x x x^{+}}$

$\underline{\mathrm{Rp}, x \times x x}$

Rp.xxxx 
Beban terikat adalah beban yang berasal dari aliran keluar atas kas atau non-kas yang penggunaannya dibatasi oleh pihak ketiga. Beban tidak terikat adalah beban yang berasal dari aliran keluar kas atau non-kas yang penggunaannya tidak dibatasi oleh pihak ketiga. Pendapatan tidak terikat adalah sumbangan, jasa layanan, penghasilan investasi yang berasal dari pihak ketiga dan bersifat tidak mengikat, merupakan bagian dari pendapatan tidak terikat. Pendapatan terikat adalah pendapatan yang berasal dari aliran massuk atas kas atau non-kas yang penggunaannya dibatasi oleh pihak ketiga.

Desain sistem pengelolaan informasi akuntansi yaitu sistem yang terkait pada organisasi nirlaba adalah

\section{IPO Pembelian Tunai}

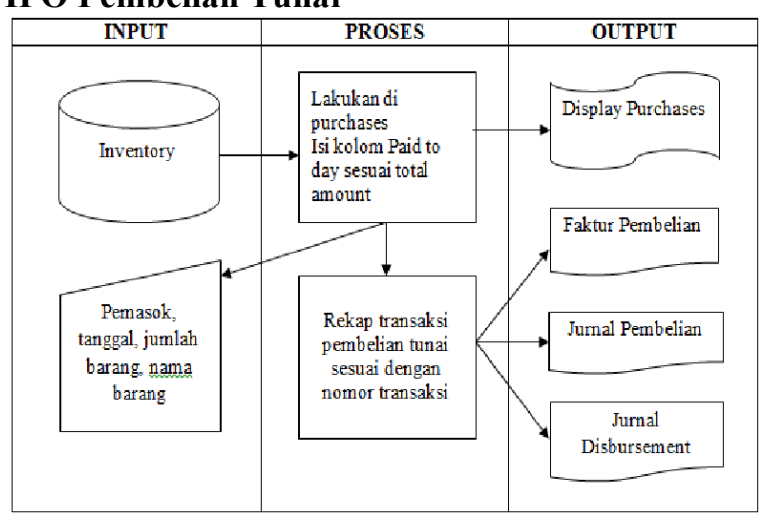

\section{IPO Penjualan Tunai}

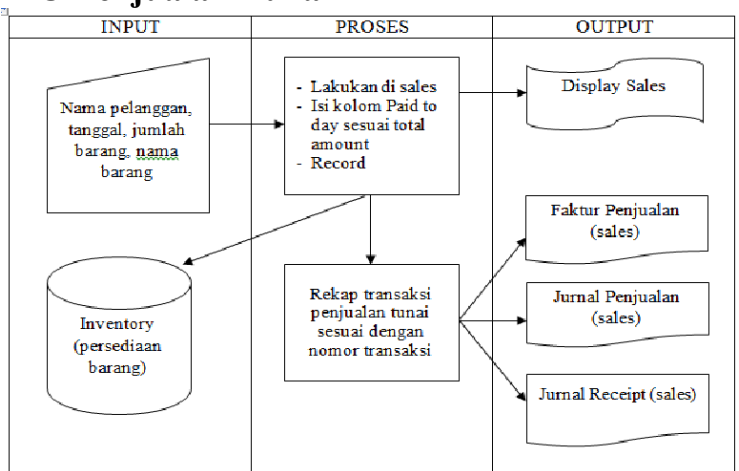

\section{IPO Pembelian Kredit}

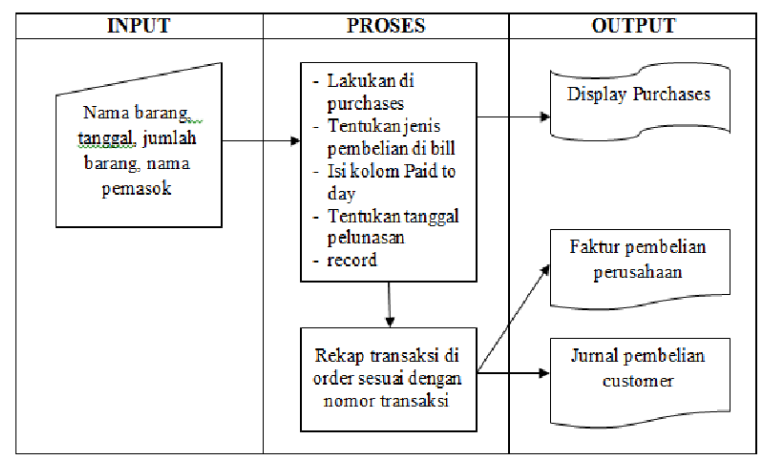

IPO Penjualan Kredit

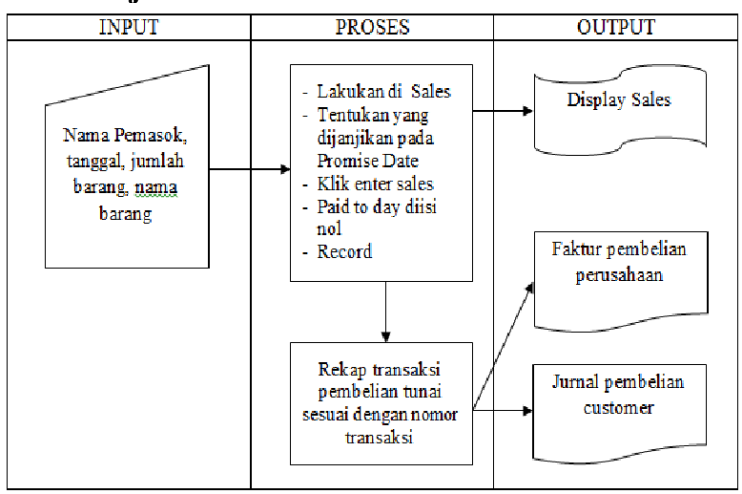

Desain Sistem Informasi Dan Laporan Keuangan 
IPO Penerimaan Piutang

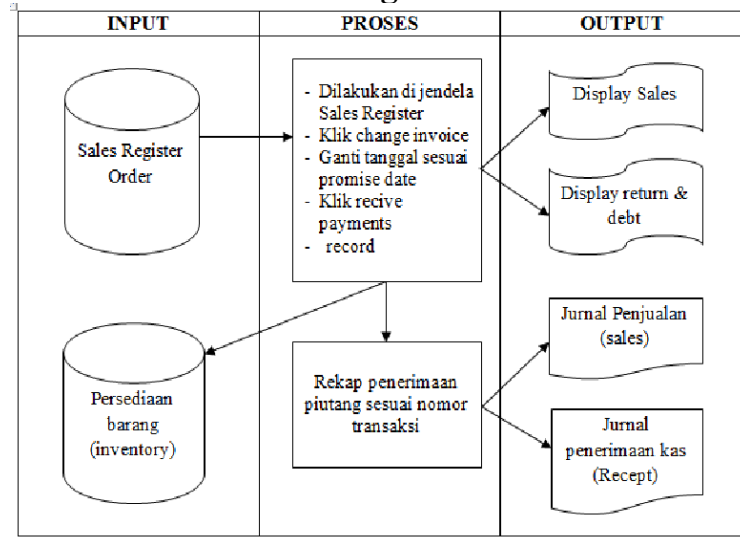

\section{KESIMPULAN}

Desain sistem dan prosedur pengelolaan informasi akuntansi nirlaba adalah pencatatan transaksi organisasi nirlaba dari penerimaan kas, pengeluaran kas, pembelian, penjualan produk/jasa, penyusutan tidak ada perbedaannya dengan organisasi bisnis. Pada organisasi nirlaba pihak yang menjadi pemilik, hingga tidak ada transaksi yang berhubungan dengan penjualan/perubahan kepemilikan, atau tidak adanya alokasi dana atau sumber daya hasil likuidasi. Tidak akan ada transaksi yang digunakan untuk pembagian laba kepada pendiri atau pemilik. Mengingat organisasi nirlaba memerlukan laporan keuangan untyuk menyediakan informasi yang relevan dan untuk memenuhi kepentingan para penyumbang, anggota organisasi, kreditur dan pihak.

Laporan posisi keuangan yaitu neraca (balance sheet) untuk organisasi nirlaba formatnya sama dengan laporan keuangan bisnis. Namun ada perbedaan yang signifikan yaitu terdapat akun aktiva terkait pada bagian aktiva/asset. Akun tersebut adalah akun untuk menunjukkan bahwa aktiva tersebut dibatasi penggunaannya. Aktiva yang dibatasi penggunaannya oleh penyumbang harus disajikan terpisah dari kas atau aktiva lain yang tidak terikat penggunaannya.

Prinsip dasar laporan Aktivitas Nirlaba (Laporan Perubahan Aktiva Bersih) adalah usaha untuk mengklasifikasikan penghasilan, sumbangan, beban, dan kerugian berdasarkan jenis ikatan kontraknya.

Berdasarkan simpulan di atas, maka sisitem informasi akuntansi pada organisasi nirlaba yang sifatnya masih konvensional diganti dengan sistem yang berbasis komputer sehingga diharapakan dapat meminimalisir kelemahan sistem yang lama sehingga informasi menjadi lebih akurat dan tepat waktu.

\section{REFERENSI}

[1] Jogiyanto HM. 2005. Analisis \& Desain Sistem Informasi : Pendekatan Terstruktur Teori dan Praktek Aplikasi Bisnis. Yogyakarta. Andi.

[2] Nainggolan, Deddy. 2006. Akuntansi Sektor Publik. Penerbit. Salemba Empat, Jakarta

[3] Nordiawan, Deddy. 2006. Akuntansi Sektor Publik. Penerbit: Salemba Empat, Jakarta

[4] Romney, Marshall B., Stembart, Paul John. 2000. Accounting Information System (8th ed.). New Jersey : Prentice Hall

[5] Sulistiawan, Dhedy. 2007. Akuntansi Nirlaba Menggunakan Accurate. Penerbit: PT. Elex Media Komputindo, Jakarta 